\title{
Tra Vinh University and strategies heading to green campus
}

\author{
Nguyen Thi Mai Khanh* \\ Department for International Collaboration and Project Promotion, Tra Vinh University, Vietnam
}

\begin{abstract}
Tra Vinh University (TVU), the only university in the province for developing labour force in Tra Vinh. This article is to share the strategies that Tra Vinh University used to make the university become green. Being aware that environtment and climate change are issues should be concern as its impact to human life, Tra Vinh University identidied green campus is one of the mission that have to be done along with the development of the university. Different strategies have been applied and bring Tra Vinh University significant affect in terms of energy saving and green activities through the university curriculum, green projects and environment tracking in different aspesct. One of the environment issues that has been carried out frequently is waste water from daily activities and laboratories. The waste water is check physically and via database from the labs in different time of the year. The positive result from the test gives good signals to TVU's green target.
\end{abstract}

\section{Introduction}

Tra Vinh University (TVU) is located in the Mekong Delta and is the only university in Tra Vinh Province.Tra Vinh University began as Tra Vinh Community College in 2001 under the framework of the Vietnam-Canada Community College Project (VCCCP), which was funded by the Canadian International Development Agency (CIDA). The project implemented successfully the Canadian community college model in a Vietnamese context under the leadership of Dr. Pham Tiet Khanh, Rector of Tra Vinh University, and President of the Vietnam Association of Community Colleges (VACC).

TVU has the mission to provide with multi-level, multi-discipline and articulation training programs including certificate granting courses, short and longterm courses, undergraduate and postgraduate programs to all learners at all ages with special care for women, ethnic minority and people with special need. TVU responds flexibly to the long-life learning demand for learners; closely link to enterprises and employers in order to ensure skill-driven training and create the best employment opportunity for learners. TVU aims to become a typical university in professional educational system in Vietnam and success in international integration. Its motto is to "bring about quality learning opportunity for community. The vision of TVU is to become one of the best community-driven universities in not only the region, but also all of Vietnam.

As other university in the region, Tra Vinh University targets to develop the University into a Green University. Rector of Tra Vinh University has signed Talloires Declaration in 2013 as a commitment to implement the Green Project within the Campuses.

\section{Strategies heading to green campus at Tra Vinh University}

\subsection{Significant green activities}

With the target of developing a green university, Tra Vinh University has applied different strategies and organized many activities of which three main activities bring significant results since the signature of Talloires Declaration in 2013.

First of all, the green project for sustainable development in order to raise awareness of green ideas among students and staff. It was started by a project coorganized with a university in Australia, Swinburn University of Technology. The students from the two universities have been involved into variety of green activities under the framwork of the project. Also, four proposals on green campus were developed by the students with very good ideas including creating waste water treatment system.

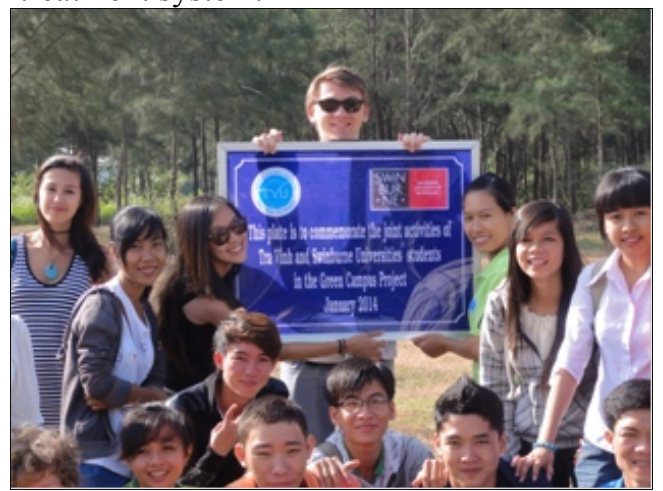

Fig. 1. The students from Tra Vinh University and Swinburn University of Technology

\footnotetext{
* Corresponding author: ntmaikhanh@tvu.edu.vn
} 
Secondly, water consumed reduction and energy saving are applied using automatic systems such as automatic taps and solar energy system for heating water at the residence. In fact, these systems help the university reduce the usage of water and electricity.

Finally, many measures applied to prevent the factors that cause damage to environment as dust and smoke, normal solid waste substance, dangerous solid waste substance, waste water and noise. The solid waste substances and waste water are collected and treated in a safe way to the environment. Especially, waste water treatment was conducted so that it does not harm the nature when it goes into the ground. The tested results of waste water can prove that the waste water on campus is safe. It is also tested by the tree planting in this source of water.

\subsection{Waste water management at Tra Vinh University}

The average volume of water using at Tra Vinh University is about $9.900-10.000 \mathrm{~m} 3 /$ month mainly for daily use of the students, staff and for gardening.

The volume of waste water from daily activities is about $6500-7000 \mathrm{~m} 3 /$ month. This waste water comes from washrooms of administration buildings, classrooms, medical clinic, labs and student residence. The waste water is collected and treated through two section septic tanks before going to the general drainage system on campus.

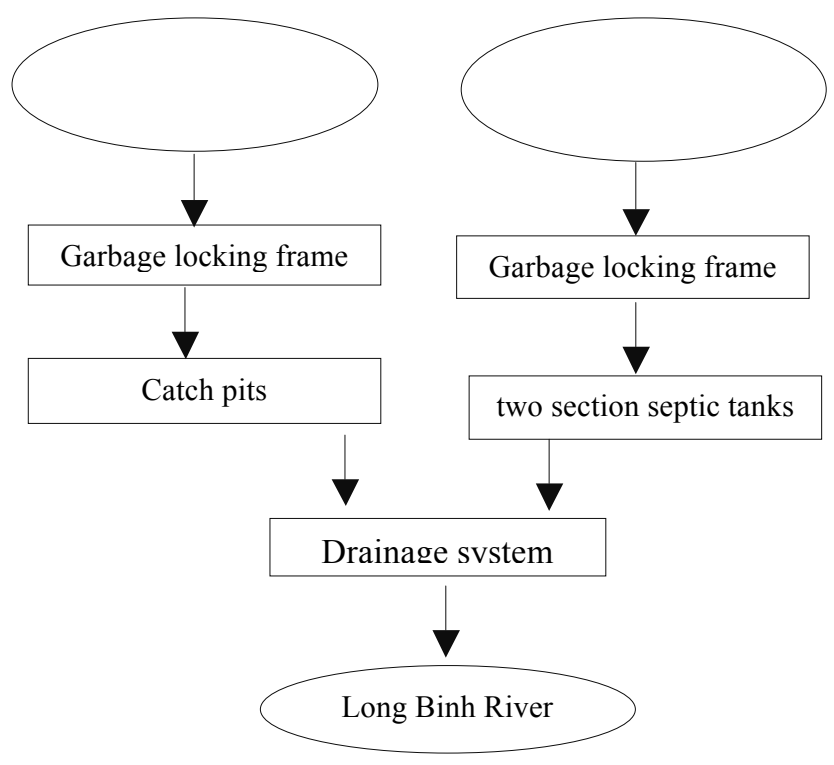

Fig. 2. Water collection and treatment on campus

Tra Vinh University has set up domestic waste water treatment system with the capacity of $560 \mathrm{~m} 3 /$ day so that waste water from campus 1 and the student residence can be collected and completely treated.

In order to control the impact of waste water on the environment, the samples of waste water from different location on Campus are collected and test every three months especially the waste water from the labs. The test result was compare with the national technical regulation to check the level of effect and pollution so that the solution of control can be implemented immediately to reduce the contamination. National technical regulation on domestic waste water QCVN 14:2008/BTNMT, National Technical Regulation on Industrial waste water QCVN 14:2011/BTNMT, National Technical Regulation on Industrial Emission of Inorganic substances and dust QCVN 19:2009/BTNMT, National Technical Regulation on Industrial Emission of Organic Substance 20:2009/BTNMT, National Technical Regulation on Noise QCVN 05:2013/BTNMT are used as a guideline for keep the campus safe from water contamination.

\subsection{Report on waste water controlled on campus:}

The tested results from the laboratory are reported base on comparison with national technical regulation as in Table 1. (2017) and Table 2. (2016). This will help the university to check if the contamination limitation of waste water on Campus.

Table 1. Laboratory result of waste water from labs in 2017

\begin{tabular}{|c|c|c|c|c|}
\hline No & Tested items & Unit & Results & $\begin{array}{c}\text { Allowed } \\
\text { limit } \\
\text { value }\end{array}$ \\
\hline 1 & $\mathrm{pH}$ & - & 7.6 & 9.0 \\
\hline 2 & $\begin{array}{l}\text { Biochemical } \\
\text { Oxygen Demand } \\
\left(\mathrm{BOD}_{5}\right)\end{array}$ & $\mathrm{mg} / \mathrm{L}$ & 15 & 60 \\
\hline 3 & $\begin{array}{l}\text { Chemical } \\
\text { Oxygen Demand } \\
(\mathrm{COD})\end{array}$ & $\mathrm{mg} / \mathrm{L}$ & 24 & 180 \\
\hline 4 & $\begin{array}{lr}\text { Turbidity } & \& \\
\text { suspendid } & \text { solids } \\
\text { (TSS) } & \end{array}$ & $\mathrm{mg} / \mathrm{L}$ & 38 & 120 \\
\hline 5 & Nitrogen $(\mathrm{N})$ & $\mathrm{mg} / \mathrm{L}$ & $<2.3$ & 48 \\
\hline 6 & Phosphorus (P) & $\mathrm{mg} / \mathrm{L}$ & 0.6 & 7.2 \\
\hline 7 & Cadimi (Cd) & $\mathrm{mg} / \mathrm{L}$ & $<0.002$ & 0.12 \\
\hline 8 & $\begin{array}{l}\text { Chromium } \\
\left(\mathrm{Cr}^{3+}\right)\end{array}$ & $\mathrm{mg} / \mathrm{L}$ & $<0.03$ & 1.2 \\
\hline 9 & $\begin{array}{l}\text { Chromium (VI) } \\
\left(\mathrm{Cr}^{6+}\right)\end{array}$ & $\mathrm{mg} / \mathrm{L}$ & $<0.03$ & 0.12 \\
\hline 10 & Manganese (Mn) & $\mathrm{mg} / \mathrm{L}$ & $<0.025$ & 1.2 \\
\hline 11 & Iron $(\mathrm{Fe})$ & $\mathrm{mg} / \mathrm{L}$ & 0.5 & 6.0 \\
\hline 12 & Zinc $(\mathrm{Zn})$ & $\mathrm{mg} / \mathrm{L}$ & 0.14 & 3.6 \\
\hline
\end{tabular}




\begin{tabular}{|c|l|c|c|c|}
\hline 13 & $\mathrm{Hg}$ & $\mathrm{mg} / \mathrm{L}$ & $<0.0005$ & 0.012 \\
\hline 14 & $\mathrm{~Pb}$ & $\mathrm{mg} / \mathrm{L}$ & $<0.005$ & 0.6 \\
\hline 15 & $\mathrm{Ni}$ & $\mathrm{mg} / \mathrm{L}$ & $<0.1$ & 0.6 \\
\hline 16 & $\mathrm{Cu}$ & $\mathrm{mg} / \mathrm{L}$ & $<0.05$ & 2.4 \\
\hline
\end{tabular}

Table 2. Laboratory result of waste water from labs in 2016

\begin{tabular}{|l|l|c|c|c|}
\hline No & \multicolumn{1}{|c|}{ Tested items } & Unit & Results & $\begin{array}{c}\text { Allowed } \\
\text { limit } \\
\text { value }\end{array}$ \\
\hline 1 & $\mathrm{pH}$ & - & 7.72 & 9.0 \\
\hline 2 & $\begin{array}{l}\text { Biochemical } \\
\text { Oxygen Demand } \\
\text { (BOD5) }\end{array}$ & $\mathrm{mg} / \mathrm{L}$ & 23.9 & 60 \\
\hline 3 & $\begin{array}{l}\text { Chemical } \\
\text { Oxygen Demand } \\
\text { (COD) }\end{array}$ & $\mathrm{mg} / \mathrm{L}$ & 103 & 180 \\
\hline 4 & $\begin{array}{l}\text { Turbidity \& } \\
\text { suspendid solids } \\
\text { (TSS) }\end{array}$ & $\mathrm{mg} / \mathrm{L}$ & 25 & 120 \\
\hline 5 & Nitrogen (N) & $\mathrm{mg} / \mathrm{L}$ & 7.01 & 48 \\
\hline 6 & Phosphorus (P) & $\mathrm{mg} / \mathrm{L}$ & 0.14 & 7.2 \\
\hline 7 & $\begin{array}{l}\text { Cadimi (Cd) } \\
\text { (Cr6+) }\end{array}$ & $\mathrm{mg} / \mathrm{L}$ & $<0.002$ & 0.12 \\
\hline 8 & $\begin{array}{l}\text { Chromium (III) } \\
\text { (Cr3+) }\end{array}$ & $<0.03$ & 1.2 \\
\hline 9 & $\begin{array}{l}\text { Chromium (VI) } \\
\text { (C)/L }\end{array}$ & $<0.03$ & 0.12 \\
\hline
\end{tabular}

\begin{tabular}{|c|l|c|c|c|}
\hline 10 & $\begin{array}{l}\text { Manganese } \\
(\mathrm{Mn})\end{array}$ & $\mathrm{mg} / \mathrm{L}$ & $<0.025$ & 1.2 \\
\hline 11 & Iron $(\mathrm{Fe})$ & $\mathrm{mg} / \mathrm{L}$ & 0.2 & 6.0 \\
\hline 12 & Zinc $(\mathrm{Zn})$ & $\mathrm{mg} / \mathrm{L}$ & 0.14 & 3.6 \\
\hline 13 & $\mathrm{Hg}$ & $\mathrm{mg} / \mathrm{L}$ & $<0.0002$ & 0.012 \\
\hline 14 & $\mathrm{~Pb}$ & $\mathrm{mg} / \mathrm{L}$ & $<0.12$ & 0.6 \\
\hline 15 & $\mathrm{Ni}$ & $\mathrm{mg} / \mathrm{L}$ & $<0.12$ & 0.6 \\
\hline 16 & $\mathrm{Cu}$ & $\mathrm{mg} / \mathrm{L}$ & $<0.06$ & 2.4 \\
\hline
\end{tabular}

\section{Summary}

The results from the two tables are for the waste water from the labs where the level of pollution is at the highest rate $[1,2]$. It is clearly that half of the tested items has significant reduction of contamination and under controlled from year to year. The others can be seen increased but not much and also under the allowed limitation of the national technical regulation. This is a good signal for waste water treatment at Tra Vinh University in developing into a green university.

In the coming years, more international sustainable development programs for students should be implemented in order to raise awareness of environment to the young people. Also, more research should be done to find out more sources of renewable energy to reduce pollutants.

\section{References}

1. Tra Vinh University, Report on Environment Observation of Tra Vinh University 2016 (2016)

2. Tra Vinh University, Report on Environment Observation of Tra Vinh University 2017 (2017) 